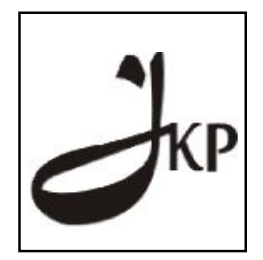

Jurnal Konseling dan Pendidikan

ISSN Cetak: 2337-6740 - ISSN Online: 2337-6880

http://jurnal.konselingindonesia.com

Volume 3 Nomor 2, juni 2015, HIm 49-54

Info Artikel:

Diterima 06/06//2015

Direvisi 12/06/2015

Dipublikasikan 30/06/2015

\title{
Peningkatan Kematangan Emosi Anak Bungsu melalui Layanan Bimbingan Kelompok
}

Annajmi Alfath, Taufik \& Indra Ibrahim

Universitas Negeri Padang

\section{Abstract}

Sekolah merupakan salah satu lembaga pendidikan formal yang bertujuan mendewasakan anak didik, sehingga mereka dapat mencapai tugas perkembangan yang optimal. Tugas perkembangan yang ingin dicapai salah satunya adalah mencapai kematangan emosi. Namun pada kenyataannya tidak semua siswa mencapai kematangan emosinya dengan baik, khususnya anak bungsu. Berdasarkan fenomena yang ada di MTsN Gurun Panjang dapat diketahui bahwa beberapa anak bungsu belum melihatkan kematangan emosinya. Melalui bimbingan kelompok diharapkan kematangan emosi anak bungsu dapat ditingkatkan. Tujuan penelitian ini untuk mengetahui keberhasilan dalam meningkatkan kematangan emosi anak bungsu. Metode penelitian yang digunakan adalah pra-eksperimental dengan teknik one group pre-test post-test design. Subjek dalam penelitian ini adalah anak bungsu. Teknik pengumpulan data menggunakan angket berskala. Data dianalisis dengan teknik Wilcoxon signed rank test dengan menggunakan bantuan program Statistical Product and Service Solution (SPSS) versi 20. Dari hasil penelitian menunjukkan tingkat kematangan emosi anak bungsu sebelum diberikan layanan bimbingan kelompok berada pada kategori cukup dan setelah diberikan layanan bimbingan kelompok berada pada kategori sangat tinggi. Sehingga terdapat perbedaan yang signifikan antara tingkat kematangan emosi anak bungsu sebelum dan sesudah diberikan layanan bimbingan kelompok. Hal ini berarti terjadi peningkatan kematangan emosi setelah diberikan layanan bimbingan kelompok. Oleh karena itu, perlu upaya peningkatan kematangan emosi lebih lanjut melalui layanan bimbingan dan konseling terutama bimbingan kelompok.

Keyword: Kematangan Emosi, Anak Bungsu, Bimbingan Kelompok.

Copyright (C) 2015 IICE - Multikarya Kons (Padang - Indonesia) dan IKI - Ikatan Konselor Indonesia - All Rights Reserved

Indonesian Institute for Counseling and Education (IICE) Multikarya Kons

\section{PENDAHULUAN}

Sekolah merupakan salah satu lembaga pendidikan formal yang bertujuan mendewasakan anak didik, sehingga mereka dapat mencapai perkembangan yang optimal. Wadah untuk mencapai tujuan tersebut adalah melalui proses pendidikan khususnya di sekolah. Menurut Tohirin (2007:6) bimbingan dan konseling mempunyai peranan yang sangat penting dalam pendidikan, yaitu membantu setiap siswa agar berkembang secara optimal.

Menurut Fenti Hikmawati (2012:1) bimbingan dan konseling adalah layanan bantuan yang diberikan kepada peserta didik, baik secara perorangan maupun kelompok. Selanjutnya menurut W.S Winkel (dalam Dewa Ketut Sukardi, 2008:53) tujuan penyelenggaraan layanan bantuan dalam bimbingan dan konseling adalah berupaya untuk membimbing siswa dalam menghadapi keadaan batinnya sendiri dan mengatasi pergumulan dalam hatinya agar bisa mengatur dirinya di bidang kerohanian, perawatan jasmani, pengisian waktu luang, penyaluran nafsu seksual serta bimbingan dalam membina hubungan kemanusiaan dengan sesama dalam berbagai lingkungan.

Untuk mencapai tujuan tersebut bimbingan dan konseling memiliki layanan-layanan yang bisa digunakan. Prayitno (2004: 253) menjelaskan jenis-jenis layanan dalam bimbingan dan konseling adalah layanan orientasi dan informasi, penempatan dan penyaluran, layanan bimbingan belajar, konseling perorangan, bimbingan dan konseling kelompok, layanan konsultasi, layanan mediasi, layanan advokasi, serta kegiatan pendukung. Layanan 
bimbingan dan konseling merupakan layanan yang dapat dilaksanakan dalam sekolah maupun diluar sekolah. Siswa SMP dan SMA merupakan salah satu yang menjadi sasaran layanan bimbingan dan konseling disekolah.

Pada periode perkembangan siswa SMP dapat dikategorikan berada dalam usia remaja. Menurut Elida Prayitno (2006:6) remaja dapat dikatakan sebagai individu yang telah mengalami masa baligh atau telah berfungsinya hormon reproduksi sehingga wanita mengalami menstruasi dan pria mengalami mimpi basah. Sedangkan secara psikologis, menurut Piaget (dalam Hurlock, 1980:206) remaja adalah suatu usia dimana individu menjadi terintegrasi kedalam masyarakat dewasa, suatu usia dimana anak tidak merasa bahwa dirinya berada di bawah tingkat orang yang lebih tua melainkan merasa sama, atau paling tidak sejajar.

Pada masa ini remaja mempunyai tugas-tugas perkembangan yang harus mereka capai agar remaja bisa berkembang secara optimal. Salah satu tugas perkembangan yang harus dicapai oleh remaja adalah mencapai kemerdekaan (kebebasan) emosional dari orang tua dan orang dewasa lainnya. Hal ini disebabkan karena dalam fase ini remaja mengalami perubahan dalam sistem kerja hormon (dalam tubuh) yang memberi dampak baik pada bentuk fisik (organ-organ seksual) dan psikis terutama emosi (Atikah Proverawati dan Siti Misarah, 2009:12).

Pada remaja fungsi emosi tersebut belum berperan dalam kehidupan mereka. Karena pada periode ini remaja cenderung memperlihatkan emosi tinggi, dalam arti emosi negatif mereka lebih mudah muncul. Hal ini disebabkan remaja banyak mengalami masalah dalam kebutuhan mereka, sehingga tugas-tugas perkembangan mereka tidak tercapai (Elida Prayitno, 2006:69).

Menurut Hurlock (1980:213) ciri-ciri remaja yang sudah mencapai tugas perkembangannya adalah mempunyai kematangan emosi. Kematangan yang dimaksud adalah tidak "meledakkan" emosinya dihadapan orang lain, melainkan menunggu waktu dan tempat yang tepat untuk mengungkapkan emosinya dengan cara-cara yang baik.

Agar kematangan tersebut bisa tercapai remaja membutuhkan peranan orang-orang yang berada dalam lingkungan mereka, baik itu orang tua, masyarakat maupun guru di sekolah. Terutama pada remaja yang merupakan anak bungsu. Karena anak bungsu dan cenderung diperlakukan dengan manja oleh orang tuanya.

Agus Sujanto, dkk (2009:51) berpendapat bahwa anak bungsu mendapatkan kasih sayang yang berlebihan dari orang tua dan kakak-kakaknya. Mendapatkan banyak perhatian, perawatan, pertolongan, hiburan, maka anak bungsu seakan-akan berada di dalam kehidupan yang berkecukupan yang menyebabkan dia terbiasa hidup manja.

Menurut Adler (dalam Taufik, 2012:93) individu yang diperlakukan dengan manja akan mengakibatkan minat sosialnya rendah, namun mereka mempunyai hasrat yang kuat untuk mempertahankan hubungan yang sifatnya hanya menguntungkan dirinya pribadi. Hal yang seperti ini akan membentuk mereka menjadi individu yang tidak mandiri seperti mudah bimbang, mudah putus asa, sangat sensitif, tidak sabar dan mudah emosi.

Bimbingan dan konseling merupakan upaya yang sistematik dalam menfasilitasi individu mencapai kematangan emosi disekolah. Pelaksana bimbingan dan konseling adalah guru pembimbing atau konselor sekolah. Layanan bimbingan kelompok merupakan salah satu layanan yang tepat dilakukan oleh guru bimbingan dan konseling untuk membantu proses kematangan emosi remaja.

Berdasarkan hasil wawancara yang penulis lakukan pada tanggal 8 Maret 2014 dengan salah satu guru Bimbingan dan Konseling yang berada di sekolah MTsN Gurun Panjang di ketahui bahwa beberapa anak bungsu masih belum melihatkan kematangan pada emosinya seperti masih belum bisa mengendalikan emosinya, bahkan emosi mereka suka meledak-ledak jika sedang bermasalah dengan teman sebaya bahkan dengan guru mereka. Dan layanan bimbingan kelompok belum terlaksana dengan baik di sekolah ini, karena jumlah guru bimbingan dan konseling hanya satu orang untuk semua kelas yang berada disini.

Dari pengertian bimbingan kelompok dan fenomena yang ditemukan tersebut, penulis merasa bimbingan kelompok sangat cocok dilaksanakan untuk meningkatkan kematangan emosi anak bungsu. Sehingga penulis tertarik untuk melakukan penelitian dengan judul Peningkatan Kematangan Emosi Anak Bungsu Melalui Bimbingan Kelompok.

Dikarenakan adanya hal-hal yang telah dijabarkan di dalam fenomena maka pentingnya dilakukan penelitian ini untuk mengetahui dan mengungkap:

1. Bagaimana kematangan emosi anak bungsu sebelum diberikan layanan bimbingan kelompok

2. Bagaimana kematangan emosi anak bungsu sesudah diberikan layanan bimbingan kelompok

3. Apakah terdapat perbedaan kematangan emosi anak bungsu sebelum dan sesudah diberikan layanan bimbingan kelompok 


\section{METODOLOGI}

Penelitian ini menggunakan metode pre-eksperimen dengan desain one group pretest-posttest design. Subjek penelitian yang dilibatkan dalam penelitian ini adalah sebanyak 8 orang anak bungsu kelas VII di MTsN Gurun Panjang.

Alat yang digunakan untuk pengumpulan data dalam penelitian ini adalah kuesioner/angket. Untuk melihat deskripsi data tersebut digunakan Mean, SD (Standar Deviasi), dan persentase. Pengolahan data juga dilakukan dengan memanfaatkan program SPSS versi 20.

\section{HASIL}

Hasil penelitian secara keseluruhan tentang kematangan emosi anak bungsu sebelum dan sesudah diberikan layanan bimbingan kelompok. Berdasarkan tabel disamping diperoleh skor rata-rata hasil pretest anak bungsu adalah 74,4 dengan persentase 58,6\%, skor tertinggi 77 dan skor terendah 71. Dari penyebaran data tersebut dapat ditafsirkan bahwa tingkat kematangan emosi anak bungsu berada pada kategori cukup. Sedangkan pada hasil posttest skor rata-rata diperoleh 121 dengan persentase 94,75\%, skor tertinggi 122 dan skor terendah 120. Dari data tersebut dapat ditafsirkan bahwa tingkat kematangan emosi anak bungsu setelah diberikan layanan bimbingan kelompok berada pada kategori sangat tinggi. Hal ini ditafsirkan sesuai dengan pengklasifikasian pada tabel 4. Dengan membandingkan hasil pretest dan posttest yang dapat dilihat pada tabel 5 diketahui bahwa adanya perbedaan tingkat kematangan emosi anak bungsu sebelum dan setelah diberikan layanan bimbingan kelompok. Dimana tingkat kematangan emosi anak bungsu meningkat setelah diberikan layanan bimbingan kelompok.

Tabel Hasil Tingkat Kematangan Emosi Anak Bungsu Sebelum dan SesudahDiberikan Layanan Bimbingan Kelompok

\begin{tabular}{|c|c|c|c|c|c|c|c|}
\hline \multirow{2}{*}{ Res } & \multirow{2}{*}{ Inisial } & \multicolumn{3}{|c|}{ Pretest } & \multicolumn{3}{c|}{ Posttest } \\
\cline { 3 - 8 } & & Skor & $\%$ & Kat & $\begin{array}{c}\text { Sko } \\
\text { r }\end{array}$ & $\%$ & Kat \\
\hline 1 & JD & 76 & 60 & C & 121 & 95 & ST \\
\hline 2 & IS & 77 & 61 & T & 122 & 96 & ST \\
\hline 3 & ARP & 75 & 59 & C & 121 & 95 & ST \\
\hline 4 & DAR & 75 & 59 & C & 120 & 94 & ST \\
\hline 5 & MA & 71 & 56 & C & 120 & 94 & ST \\
\hline 6 & DJ & 75 & 59 & C & 121 & 95 & ST \\
\hline 7 & RN & 72 & 57 & C & 120 & 94 & ST \\
\hline 8 & LR & 74 & 58 & C & 121 & 95 & ST \\
\hline \multicolumn{2}{|c|}{ JUMLAH } & 595 & 469 & & 966 & 758 & \\
\hline \multicolumn{2}{|c|}{ MEAN } & 74,4 & 58,6 & C & 121 & 94,75 & ST \\
\hline
\end{tabular}

\section{PEMBAHASAN HASIL PENELITIAN}

Pada bagian ini akan dikemukakan pembahasan hasil temuan penelitian mengenai tingkat kematangan emosi anak bungsu sebelum dan sesudah diberikan layanan bimbingan kelompok. Hasil penelitian tersebut akan dibahas pada uraian berikut ini:

1. Tingkat Kematangan Emosi Anak Bungsu Sebelum Dan Sesudah Diberikan Layanan Bimbingan Kelompok

a. Tingkat Kematangan Emosi Anak Bungsu dalam Kemampuan Mengenali Emosi Sebelum dan Sesudah Layanan Bimbingan Kelompok

Temuan penelitian menunjukkan bahwa tingkat kematangan emosi anak bungsu dalam kemampuan mengenali emosi sebelum diberikan layanan bimbingan kelompok rata-rata berada pada kategori cukup. Setelah diberikan layanan bimbingan kelompok tingkat kematangan emosi anak bungsu dalam kemampuan mengenali emosi rata-rata berada pada kategori sangat tinggi. Jadi dapat disimpulkan bahwa tingkat kematangan emosi anak bungsu secara rata-rata mengalami peningkatan.

Bimbingan kelompok dapat membantu siswa dalam mengenali diri sendiri, terutama mengenali emosi-emosi yang sering muncul pada dirinya. Sebagaimana menurut Prayitno (1997:78) layanan 
bimbingan kelompok dapat membahas berbagai hal yang amat beragam dan berguna bagi siswa diantaranya menerima diri sendiri dan orang lain. Dengan adanya pembahasan ini anggota kelompok bisa memahami emosi yang ada pada dirinya sendiri dan juga orang lain disekitarnya.

Dengan demikian bimbingan kelompok bermanfaat untuk meningkatkan kematangan emosi anak bungsu dalam kemampuan mengenali emosi.

b. Tingkat Kematangan Emosi Anak Bungsu dalam Mengekspresikan Emosi dengan Baik Sebelum dan Sesudah Diberikan Layanan Bimbingan Kelompok

Temuan penelitian menunjukkan bahwa tingkat kematangan emosi anak bungsu dalam mengekspresikan emosi dengan baik sebelum diberikan layanan bimbingan kelompok berada pada ketegori cukup dan setelah diberikan layanan bimbingan kelompok tingkat kematangan emosi anak bungsu dalam kemampuan mengekspresikan emosi dengan baik berada pada kategori sangat tinggi.

Dalam mengekspresikan emosi pada masa remaja biasa yang sering terlihat adalah ledakan-ledakan kemarahan yang sering terjadi. Menurut Sunarto,dkk (2008:155) hal ini terjadi akibat kombinasi dari perubahan fisik dan ketegangan psikologis pada remaja. Cara agar membentuk remaja yang bisa mengekspresikan emosi dengan baik salah satunya adalah dengan melakukan pelatihan atau belajar dibawah bimbingan dan pengawasan (Sunarto, dkk. 2008:158).

Dengan demikian bimbingan kelompok dapat digunakan sebagai pembelajaran untuk remaja khususnya anak bungsu agar bisa mengekspresikan emosi dengan baik.

c. Tingkat Kematangan Emosi Anak Bungsu dalam Mengendalikan Emosinya Sendiri Sebelum dan Sesudah Diberikan Layanan Bimbingan Kelompok

Temuan penelitian menunjukkan bahwa tingkat kematangan emosi anak bungsu dalam mengendalikan emosinya sendiri sebelum diberikan layanan bimbingan kelompok rata-rata berada pada ketegori cukup dan setelah diberikan layanan bimbingan kelompok tingkat kematangan emosi anak bungsu dalam kemampuan mengekspresikan emosi dengan baik berada pada kategori sangat tinggi.

Menurut Dewa Ketut Sukardi (2000:444) mengungkapkan salah satu manfaat dari bimbingan kelompok adalah membantu anggota kelompok untuk tenggang rasa dalam berbicara. Hal ini menggambarkan bahwa kegiatan bimbingan kelompok dapat melatih anak bungsu untuk bisa mengendalikan emosi dalam mengemukakan pendapat.

Dengan demikian dapat disimpulkan bahwa bimbingan kelompok dapat bermanfaat untuk melatih siswa khususnya anak bungsu dalam mengendalikan emosinya sendiri.

d. Tingkat Kematangan Emosi Anak Bungsu dalam Mengendalikan Emosinya Sendiri Sebelum dan Sesudah Diberikan Layanan Bimbingan Kelompok

Temuan penelitian menunjukkan bahwa tingkat kematangan emosi anak bungsu dalam kemampuan mendengarkan dan memahami orang lain sebelum diberikan layanan bimbingan kelompok rata-rata berada pada ketegori tinggi dan setelah diberikan layanan bimbingan kelompok tingkat kematangan emosi anak bungsu dalam kemampuan mendengarkan dan memahami orang lain berada pada kategori sangat tinggi.

Menurut Kathryn dan David Geldard (2010:12) pada remaja selain individualis yang berkembang, berkembang pula kemampuan untuk berpikir secara kritis tentang orang lain dan masalah interpersonal. Mereka belajar dari perspektif mereka sendiri untuk memahami dan memaknai orang lain. Selain itu menurut Sunarto (2008:158) remaja belajar dengan cara meniru, mereka mengamati hal-hal yang membangkitkan emosi orang lain, bereaksi dengan emosi dan metode ekspresi yang sama dengan orangorang yang diamati.

Oleh karena itu bimbingan kelompok sangat berguna untuk membantu anak bungsu dalam kemampuan untuk mendengarkan dan memahami orang lain. Sesuai dengan pendapat Winkel \& Sri Hastuti (2004:565) salah satu manfaat dari bimbingan kelompok adalah agar siswa dapat memahami dan menyadari bahwa orang lain atau teman-temannya sering menghadapi persoalan, kesulitan dan tantangan yang kerap kali sama, sehingga bisa membantu mereka dalam memahami dirinya sendiri.

2. Peningkatan Kematangan Emosi Anak Bungsu Setelah Diberikan Layanan Bimbingan Kelompok

Kematangan emosi menurut Chaplin (2008:165) suatu tingkat dari perkembangan emosional. Perkembangan emosional yang bagus akan menggambarkan kesehatan pada emosinya, hal ini dilihat dari berbagai aspek, menurut Tanya Byron (2000:259) yaitu sebagai berikut: a) dapat mengenali emosi, b) dapat 
mengekspresikan emosi dengan baik, 3) dapat mengendalikan emosinya sendiri dan 4) dapat mendengarkan dan memahami orang lain.

Dalam pelaksanaan layanan bimbingan kelompok menyediakan kesempatan bagi siswa untuk berkomunikasi lebih efektif sehingga berdampak juga pada peningkatan kematangan emosinya. Karena materi-materi yang dibahas dalam bimbingan kelompok akan membantu siswa dalam proses kematangan emosinya. Sesuai dengan pendapat Prayitno (1995:188) bahwa materi yang diberikan dalam bimbingan kelompok salah satunya berhubungan dengan bidang sosial, yaitu pengendalian emosi, penanggulangan konflik dan permasalahan-permalasahan yang timbul dalam masyarakat. Dan selanjutnya Winkel (1991:469) bimbingan kelompok berguna oleh konselor untuk memberikan suatu informasi pada siswa salah satunya adalah menyangkut tugas-tugas perkembangan remaja yang salah satunya adalah mencapai kematangan emosi.

Penelitian ini membuktikan bahwa pembelajaran yang dilakukan oleh guru pembimbing dengan menggunakan layanan bimbingan kelompok sangat efektif untuk membantu kematangan emosi anak bungsu. Bimbingan kelompok memberikan dampak positif dalam kematangan emosi anak bungsu, baik itu dalam mengenali emosi, mengekspresikan emosi, mengendalikan emosi serta memahami dan mendengarkan orang lain. Dengan demikian dapat dikatakan layanan bimbingan kelompok dapat berpengaruh terhadap peningkatan kematangan emosi anak bungsu.

\section{KESIMPULAN DAN SARAN}

Berdasarkan hasil penelitian tentang Peningkatan Kematangan Emosi Anak Bungsu Melalui Layanan Bimbingan Kelompok dapat disimpulkan sebagai berikut:

1. Tingkat kematangan emosi anak bungsu sebelum diberikan layanan bimbingan kelompok berada pada kategori sedang

2. Tingkat kematangan emosi anak bungsu setelah diberikan layanan bimbingan kelompok berada pada kategori tinggi

3. Terdapat perbedaan yang signifikan antara tingkat kematangan emosi anak bungsu sebelum dan setelah diberikan layanan bimbingan kelompok, dimana tingkat kematangan emosi emosi anak bungsu mengalami peningkatan, dari tingkat kematangan emosi sedang menjadi tinggi.

Berdasarkan hasil penelitian yang telah dijabarkan, maka dapat dikemukakan beberapa saran sebagai berikut:

1. Kepada guru BK yang belum melaksanakan layanan bimbingan kelompok di sekolah, diharapkan agar dapat melaksanakan layanan bimbingan kelompok disekolah untuk membantu mengentaskan masalah siswa, khususnya masalah yang berkaitan dengan perkembangan emosional siswa. Seterusnya bagi guru BK yang telah melaksanakan bimbingan kelompok di sekolah, hendaknya lebih meningkatkan dan mengembangkan metode agar dalam bimbingan kelompok agar hasil yang didapatkan lebih maksimal dalam meningkatkan kematangan emosi siswa.

2. Kepala sekolah, untuk lebih memperhatikan pelaksanaan layanan bimbingan dan konseling di sekolah. Terutama dalam penyediaan dan pengadaan sarana dan prasarana yang diperlukan guru BK dalam melaksanakan layanan bimbingan kelompok.

3. Guru mata pelajarandiharapkan dapat mengembangkan metode kelompok dalam proses pembelajaran, agar siswa lebih mudah dalam berhubungan sosial dengan teman sebaya dan melatih siswa untuk saling memahami dan mendengarkan satu sama lainnya serta bisa melatih siswa untuk bisa mengendalikan emosi dalam mengemukakan pendapat.

4. Jurusan Bimbingan dan Konseling Faklutas Ilmu Pendidikan Universitas Negeri Padang, agar lebih mempersiapkan bahan dalam rancangan program bimbingan konseling

5. Bagi peneliti selanjutya dapat melakukan penelitian ini dengan menggunakan subjek penelitian yang lain serta menggunakan jenis layanan bimbingan konseling yang lain, seperti layanan konseling individual dan layanan konseling kelompok untuk membantu meningkatkan kematanan emosi siswa.

\section{KEPUSTAKAAN}

Atikah Proverawati \& Siti Misarah. 2009. Menarche. Yogyakarta: Nuha Medika.

Dewa Ketut Sukardi. 2008. Pengantar Pelaksanaan Program Bimbingan dan Konseling di Sekolah. Jakarta:Rajawalipress. 
Elida Prayitno. 2006. Psikologi Perkembangan Remaja. Padang: Angkasa Raya.

Elizabeth B Hurlock. 1980. Psikologi Perkembangan Suatu Pendekatan Sepanjang Rentang Kehidupan (Edisi Kelima). Jakarta: Erlangga.

Elizabeth B Hurlock. 1993. Psikolgi Perkembangan Anak Jilid 1. Alih Bahasa:Meitasari Tjandra. Jakarta:Erlangga (Edisi ke-6).

Kathryn Geldard \& David Geldard. 2010. Konseling Remaja Pendekatan Proaktif Untuk Anak Muda (Diterjemahkan oleh Pustaka Pelajar). Jogjakarta:Pustaka Pelajar.

Prayitno. 1995. Layanan Bimbingan dan Konseling Kelompok (dasar dan profil) . Padang: BK UNP

Prayitno. 2006. L1-L9. Padang:BK FIP UNP.

Prayitno\& Erman, A. 2004. Dasar-dasar Bimbingan dan Konseling. Jakarta: Rineka Cipta.

Riduwan. 2007. Belajar Mudah Penelitian Untuk Guru, Karyawan dan Peneliti. Bandung: Alfa Beta.

Riduwan. 2010. Belajar Mudah Penelitian Untuk Guru, Karyawan dan Peneliti. Bandung: Alfa Beta.

Septia Ningsih, dkk. 2013. Pengaruh Bimbingan Kelompok terhadap Peningkatan Kematangan Emosi Anak bungsu Kelas XII IPS SMA Muhammadiyah Satu Pekanbaru T.A 2012/2013. Riau:BK FKIP.

Sunarto,dkk. 2008. Perkembangan Peserta Didik. Jakarta:Rineka Cipta.

Tanya Byron. 2008. Your Child Year by Year (Ensiklopedia Perkembangan Anak) edisi terjemahan oleh Erlangga. Jakarta:Erlangga.

Taufik. 2012. Model-model Konseling. Padang:BK FIP UNP.

Tohirin. 2007. Bimbingan dan Konseling di Sekolah dan Madrasah (Berbasis Integrasi). Jakarta:Raja Grafindo.

WS, Winkel. 1991. Bimbingan dan Konseling di Institusi Pendidikan. Jakarta:Gramedia Widiasarana Indonesia.

Winkel \& Sri Hastuti. 2004. Psikologi Sosial. Bandung:PT Eresco. 